\title{
Acil Serviste Takip Edilen İntihar Girişimlerinin Maliyet Analizi*
}

\section{Cost Analysis of Suicide Attempts Followed by Emergency Department}

\author{
Alp YILMAZa , Serkan DOĞAN ${ }^{\mathrm{b}}$, Utku Murat KALAFAT ${ }^{\mathrm{c}}$, Rabia Birsen TAPKAN ${ }^{\mathrm{d}}$, \\ Ali SAĞLIK ${ }^{\mathrm{e}}$ Doğaç Niyazi ÖZÜCELİK
}

\begin{abstract}
ÖZ Amaç: İntihar, kişinin istemli olarak kendi kendine zarar vermesidir. Sağlık hizmetini üretebilmesi için harcadığ 1 üretim faktörlerinin para ile ölçülebilen değeri maliyet analizi şeklinde tanımlanmaktadır. Bu çalışmada başvuru, tanı ve tedavi süreçlerinin neredeyse tamamının Acil Servislerde gerçekleştiği intihar eylemlerindeki hastaların acil ve hastane sürecindeki maliyet analizi araştırılmıştır. Gereç ve Yöntem: Çalışmada Sağlık Bilimleri Üniversitesi Kanuni Sultan Süleyman Eğitim ve Araştırma Hastanesi Acil Servisine intihar girişimi ile başvurmuş olan, dosyası ve bilgisayar kayıtları tam olan 18 yaş ve üzeri 120 hastanın verileri geriye dönük değerlendirildi. Her hastanın hastane otomasyon sistemine kaydedilen muayene, tetkik, tedavi ve konsültasyon maliyet ücretleri değerlendirildi. Bulgular: 120 hastanın yaş ortalaması 30.35 \pm 10.18 bulunurken, 18-24 yaş arasında daha fazla başvuru olduğu görüldü. Hastaların \%73.3'ü kadındı ve tüm hastaların \%56.7'si evliydi. Hastaların \%10.8'inin daha önce intihar öyküsü vardı. İntihar girişim şekli olarak en sık ilaç veya toksik madde alımı (\%94.2) seçilmişti. Hastaların \%33.3'üne psikiyatri konsültasyonu istenmişti. Hastaların \%53.3'ü acil servisten şifa ile taburcu olurken, \%18.4'üne yoğun bakım, \%5'ine serviste yatış endikasyonu verilmişti. Yalnız bir hasta acil serviste eksitus olmuştu. Hastaların acil maliyet bedelleri (ortalama $172.25 \pm 76.65 \mathrm{TL}$; en az 15.5 TL en çok $510 \mathrm{TL}$ ) hastane maliyet bedellerine yakın $(76.50 \pm 78.81 \mathrm{TL})$ bulundu. Acilde servisteki kalış süreleri ile hizmet bedeli arasında pozitif yönlü (kalış süresi arttıkça hizmet bedeli de artan) ve istatistiksel olarak anlamlı ilişki saptanmıştır ( $\mathrm{r}=0,490 ; \mathrm{p}=0,001)$.

Sonuç: İntihar eylemi ile başvuran hastaların yaklaşık yarısının tanı ve tedavi süreci Acil Serviste tamamlanmaktadır. Acilde kalış süresinin uzaması toplam maliyeti istatistiksel olarak arttırmaktadır. Bu hastaların tanı ve takip sürecinde yeni protokoller geliştirilmelidir.
\end{abstract}

Anahtar kelimeler: Acil Servis, Intihar Girişimi, Maliyet

\begin{abstract}
Aim: Suicide is a person's voluntary self-harm. The cost factors that can be measured by money are defined as cost analysis. In this study, the cost analysis of the patients' emergency and hospital processes was investigated in the suicide actions in almost all of the referral, diagnosis and treatment processes in the Emergency Department (ED). Methods: In the study, the data of 18 years old and over 120 patients who had applied to the Emergency Department of Kanuni Sultan Süleyman Education and Research Hospital of Health Sciences University with suicide attempt and computer records were retrospectively evaluated. The cost of examination, examination, treatment and consultation recorded in each hospital's hospital automation system was evaluated. Results: The mean age of the patients was $30.35 \pm 10.18$, while there were more patients between the ages of $18-24.73 .3 \%$ of the patients were female and $56.7 \%$ of all patients were married. $10.8 \%$ of the patients had suicide history previously. The most frequent type of suicide attempt was drug or toxic substance intake (94.2\%). 33.3\% of the patients were asked for a psychiatric consultation. 53.3\% of the patients were discharged with ED, $18.4 \%$ were given intensive care and 5\% were hospitalized. Only one patient died in the ED. Costs of the patients in ED (average 172.25 \pm 76.65
\end{abstract}

Geliş Tarihi:13-11-2017 / Received/ Kabul Tarihi/Accepted:14-01-2018

${ }^{a}$ Dr.,İstanbul S.B.Ü. Kanuni Sultan Süleyman Eğitim ve Araştırma Hastanesi Acil Tıp Kliniği, İstanbul, Türkiye alpylmz@hotmail.com, ORCID:

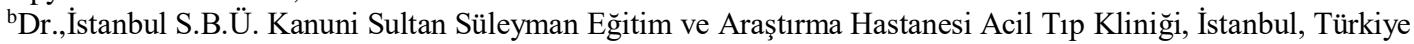
ercem2003@hotmail.com, ORCID:

${ }^{c}$ Dr.,İstanbul S.B.Ü. Kanuni Sultan Süleyman Eğitim ve Araştırma Hastanesi Acil Tıp Kliniği, İstanbul, Türkiye utkumuratk@yahoo.com, ORCID:

${ }^{\text {d} D r ., I ̇ s t a n b u l ~ S . B . U ̈ . ~ K a n u n i ~ S u l t a n ~ S u ̈ l e y m a n ~ E g ̆ i t i m ~ v e ~ A r a s ̧ t ı r m a ~ H a s t a n e s i ~ A c i l ~ T ı p ~ K l i n i g ̆ i, ~ I ̇ s t a n b u l, ~ T u ̈ r k i y e ~}$ dr.rabish@gmail.com, ORCID:

eDr., Kanuni Sultan Süleyman Eğitim ve Araştırma Hastanesi Acil Tıp Kliniği, İstanbul, Türkiye alisaglik83@hotmail.com fProf. Dr. İstanbul Üniversitesi Sağlik Bilimleri Fakültesi, İstanbul, Türkiye, dogacniyazi@ gmail.com

Sorumlu Yazar /Correspondence: Prof. Dr. NDoğaç Niyazi Özüçelik, İstanbul Üniversitesi Sağlık Bilimleri Fakültesi, İstanbul, Türkiye, dogacniyazi@gmail.com 
TL) were close to hospital cost values $(76.50 \pm 78.81 \mathrm{TL})$. There was a statistically significant relationship between the length of stay (LOS) in ED and service cost $(r=0.491, p=0.001)$. Conclusion: Approximately half of the patients who applied with suicidal action completed the diagnosis and treatment process in ED. The LOS in the ED increases the total patient cost. New protocols should be developed in the diagnosis and follow-up of these patients.

Key words: Emergency Department, Suicide, Cost Analysis

\section{Giriş}

İntihar, kişinin istemli olarak öz benliğine yönelik bir saldırganlık olup, kendi kendine zarar vermesidir (1). Dünya Sağlı Örgütü intiharı, intihar girişimi ve intihar eylemi olarak iki gruba ayırmıştır. İntiharın ölümle sonuçlanmasını intihar eylemi, ölümcül olmayan tüm girişimleri de intihar girişimi olarak değerlendirmiştir (2).

Tüm dünyada intihar düşüncesi ve girişimi sebebiyle Acil Servis (AS)'lere başvuran hastalarla oldukça yüksek oranda karşılaşılmaktadır (3). İntiharın sosyodemografik risk etmenleri arasında erkek cinsiyeti, yoksulluk, işsizlik, bekarlık, ergenlik, boşanmış, dul ya da ayrı yaşıyor olma gibi durumlar sayılabilir (4). Ayrıca hastalarda önceden olan psikiyatrik sorunların varlığı, eski intihar girişimleri ve madde bağımlılığı gözlenmiştir (5). AS'ler intihar düşüncesi ve girişimi sonucu başvuran hastaların hayati tehlikelerini ortadan kaldırdıktan ve tedavisini tamamlandiktan sonra psikiyatri tarafindan değerlendirilmesi önem arz etmektedir (6).

Hastanenin kendi faaliyet konusunu oluşturan sağlık hizmetini üretebilmesi için harcadığı üretim faktörlerinin para ile ölçülebilen değeri maliyet analizi olarak tanımlanabilir (7). Doğrudan maliyet hesaplamaları; ilaç harcamaları, tanısal incelemelere ait harcamalar, hastalığın takibiyle ilgili giderler, poliklinik ve acil harcamaları ve hastane yatışlarını içermektedir (8). Literatür de intihar girişimi sebebiyle acil servise getirilen hastalardaki maliyet analizi ile ilgili veriler sınırlıdır. Ülkemizde yapılan bir çalışmada intihar girişimlerinin hastane maliyetlerini 405,1TL (Türk Lirası) olarak bildirilmiştir (9).

Biz bu çalışmada; başvuruların tamamının Acil Servislere yapıldığı, acil stabilizasyon sürecinin tamamının AS'lerde gerçekleştirildiği ve büyük çoğunluğunun taburculuğuna kadar geçen sürenin AS'lerde tamamlandığ intihar eylemlerindeki AS ve Hastane maliyet analizini değerlendirdik.

\section{Gereç ve Yöntem}

Bu çalışma 01 Ekim 2014'den 01 Ekim 2015'e kadar olan bir yıllık dönemde Sağlık Bilimleri
Üniversitesi İstanbul Bakırköy Dr. Sadi Konuk Eğitim ve Araştırma Hastanesi Klinik Araştırmalar Etik Kurulu'nun 14.08.2017 tarihli ve 2017-09-13 sayılı onamı ile İstanbul Kanuni Sultan Süleyman Eğitim ve Araştırma Hastanesi Acil Tıp Kliniğinde gerçekleştirilen retrospektif, tanımlayıcı bir çalışmadır. Çalışmada intihar girişimi nedeniyle Acil Tıp Kliniği‘ne başvurmuş olanlardan, dosyası ve bilgisayar kayıtları olan 18 yaş ve üzeri 120 hastanın verileri geriye dönük değerlendirildi. Dosyları taranan hastaların başvuru tarih ve saati, yaş, cinsiyet, şikâyetleri, eğitim durumu, medeni durumu, iş durumu, kişinin önceki psikiyatrik öyküsü, aile öyküsü, intihar şekli, intihar saati, intihar nedenleri, yapılan tedavi, istenilen tetkikler, psikiyatri ve diğer bölüm konsültasyonları, acilde kalış süresi, sonuç ve hizmet maliyetlerinin olduğu çalışma formu oluşturulmuştur. $\mathrm{Bu}$ çalışmada maliyet bedel olarak bir hastanın hastane otomasyon sistemine kaydedilen muayene, tetkik, tedavi ve konsültasyon ücretleri değerlendirildi. İstatistiksel analizler için NCSS (Number Cruncher Statistical System) 2007 (Kaysville, Utah, USA) programı kullanıldı. Anlamlılık $\mathrm{p}<0.05$ düzeyinde değerlendirildi.

\section{Bulgular}

Çalışma \%26.7'si (n=32) erkek, \%73.3'ü $(n=88)$ kadın olmak üzere 120 olgu ile gerçekleştirilmiştir. Olguların yaşları 18 ile 56 arasında değişmekte olup, ortalama yaş $30.35 \pm 10.18$ bulunmuş ve en fazla yaş aralığı olarak 18-24 yaş grubu $(n=44)$ saptanmıştır.

İntihar girişiminde bulunan hastaların $\% 50$ 'sinin $(\mathrm{n}=60)$ ilkokul-ortaokul mezunu olduğu görülürken, \%35'i (n=42) Lise, \%6.7'sinin ( $\mathrm{n}=8)$ Üniversite, \%6.7'sinin (n=8) okur-yazar ve \%1.6'sının (n=2) okur-yazar olmadığı saptanmıştır.

İntihar eyleminin en fazla evlilerde gerçekleşmiş olduğu $(\% 56.7 \quad \mathrm{n}=68)$ görülürken, \%35.8'inin $(n=43)$ bekar, \%4.2'sinin $(n=5)$ ayr1 yaşadığ 1 , \%2.5'inin $(n=3)$ nişanlı ve \%0.8'inin $(n=1)$ dul olduğu görülmüştür. 


\section{intihar Saati}

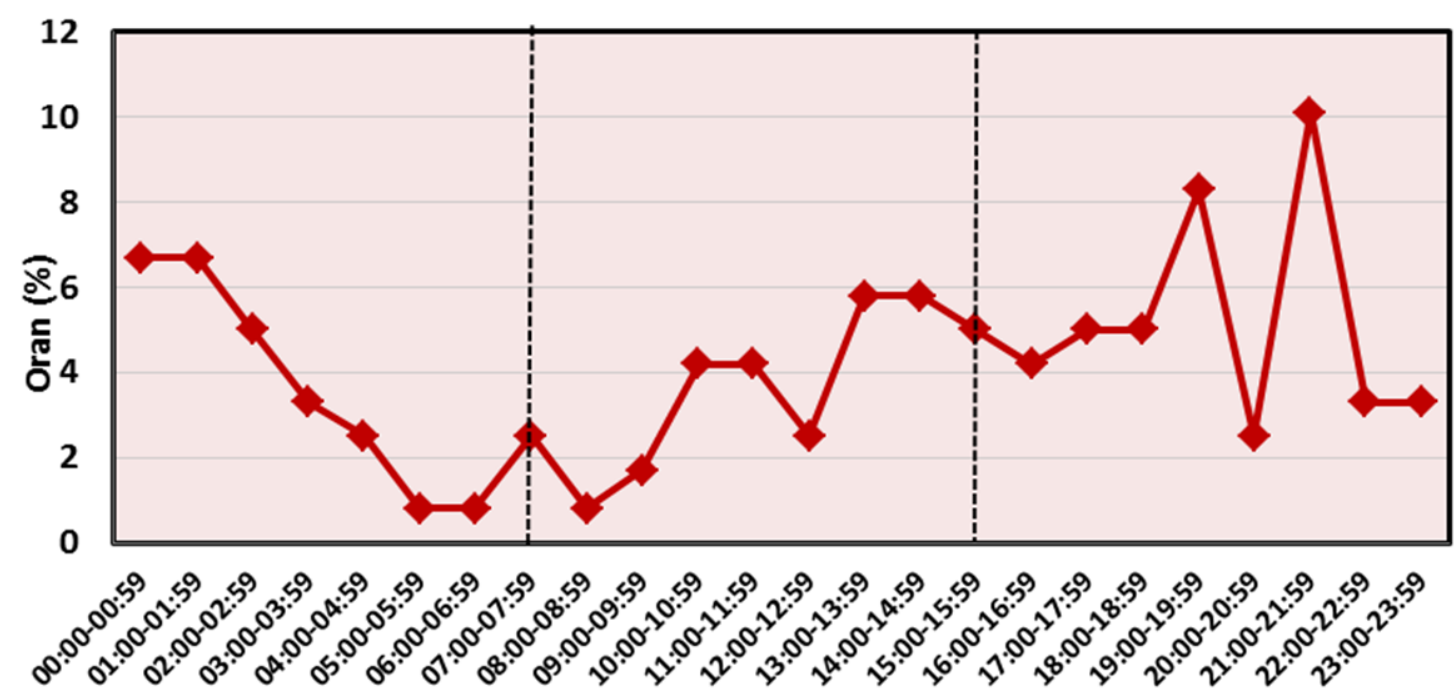

Şekil 1: İntihar saatlerinin dağılımları

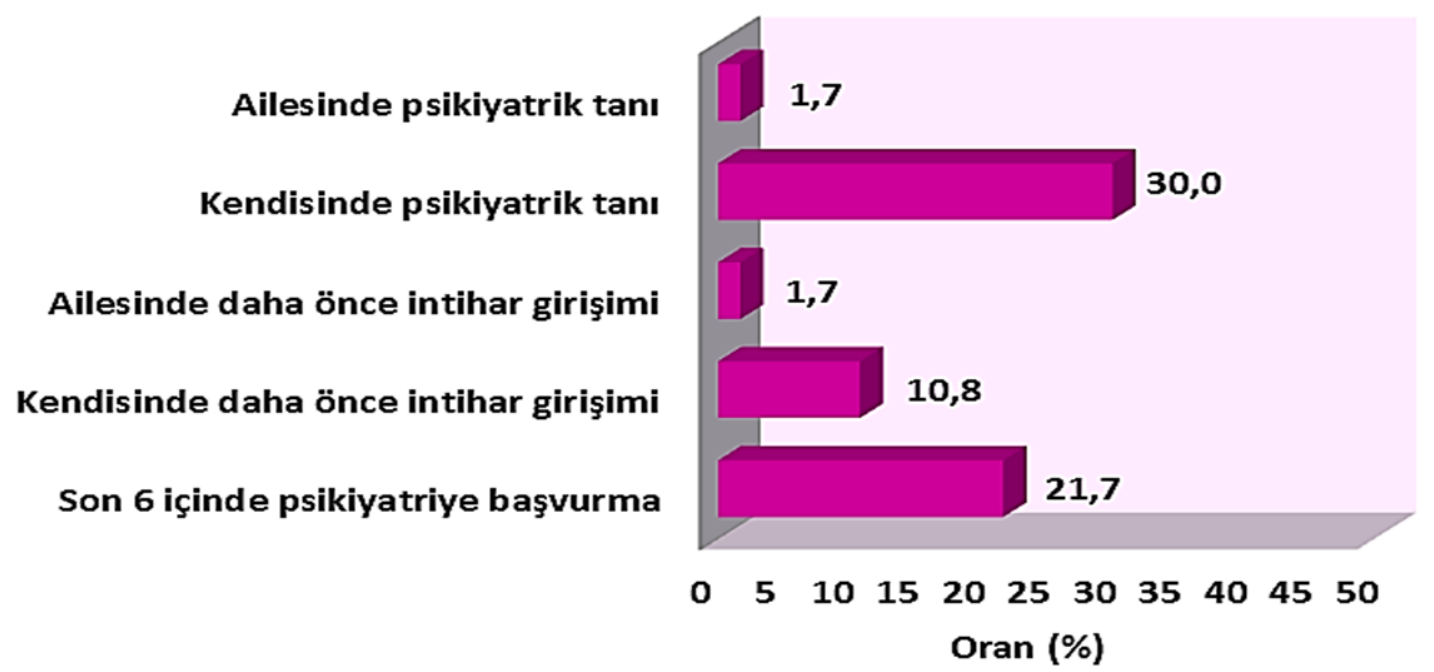

Şekil 2: İntihar girişimi ve psikiyatriye başvurma öyküsüne ilişkin dağılımlar

$\mathrm{Bu}$ çalışmada olguların \%38.3'ünün $(\mathrm{n}=46)$ çalışıyor olduğu, geri kalanının çalışmıyor olduğu (\%28.3'ü işsiz ( $\mathrm{n}=34), \% 25.8$ 'i $(\mathrm{n}=31)$ ev hanımı, \%7.5'i (n=9) öğrenci) bulundu. Erkek olguların \%68.2'si (n=15) evli ve çalışıyor olduğu kadın olguların ise \%68.7'si $(\mathrm{n}=11)$ evli ve çalışmıyor olduğu saptanmıştır.
İntihar saatleri incelendiğinde; en çok $\% 10.1(\mathrm{n}=12)$ oranla 21:00-21:59 saat aralı̆̆ında intihar eyleminin yapılmış olduğu gözlenmiştir (Şekil 1).

Başvuru saatleri incelendiğinde; en çok $\% 8.3(\mathrm{n}=10)$ oranla $18: 00-18: 59$ ve 22:00-22:59 


\section{Intihar Sebebi}

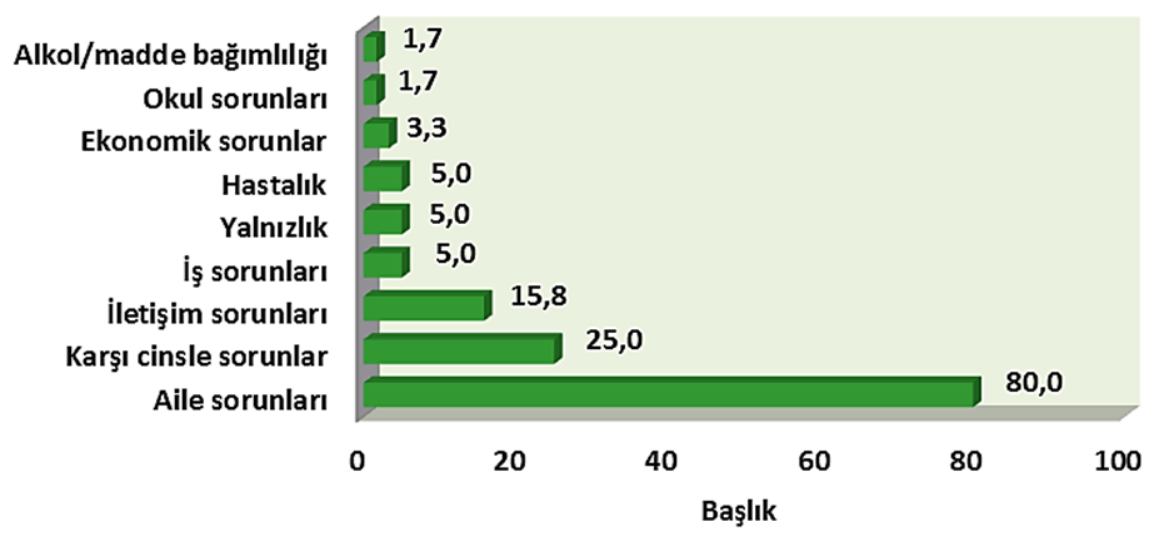

saat aralığında başvuru yapıldığı ve onu \% $7.5(\mathrm{n}=9)$ ile 14:00-14:59, \%6.7 $(\mathrm{n}=8)$ ile 01:00-01:59 ve 03:00-03:59 saat aralıklarının takip ettiği gözlenmiştir. En düşük \%0.8 $(\mathrm{n}=1)$ oranla ise 09:00-09:59 saat aralıklarında başvuru yapıldığ 1 gözlenmiştir.

Olguların \%21.7'si $(n=26)$ son 6 ay içinde psikiyatriye başvuruda bulunmuştur; \%10.8'inin $(n=13)$ kendisinde, \%1.7' $\operatorname{sinin}(n=2)$ ailesinde daha önce intihar girișimi gözlenmiștir; \%30'unun $(\mathrm{n}=36)$ kendisinde, \%1.7'sinin $(\mathrm{n}=2)$ ise ailesinde psikiyatrik tanı gözlenmiştir.

İlaç veya toksik madde ile intihar etme oran1 \%94.2 $(\mathrm{n}=113)$, kesici alet ile intihar etme oran1 $\% 2.5(\mathrm{n}=3)$, kendini asarak intihar etme oran $\% 1.7(\mathrm{n}=2)$, ateşli silah ile intihar etme oran $1 \% 0.8$ $(\mathrm{n}=1)$ ve yüksekten atlayarak intihar etme oranı $\% 0.8(\mathrm{n}=1)$ bulunmuştur.

Intihar sebepleri incelendiğinde; olguların $\% 80$ 'inin $(n=96)$ aile sorunları nedeni ile intihar ettiği saptanmıştır (Şekil 2).

Taburcu olma oran1 $\% 53.3(\mathrm{n}=64)$, tedaviyi reddetme oran1 $\% 22.5(\mathrm{n}=27)$, sevk oran $1 \% 18.4$ $(n=22)$, yatıs oranı $\% 5.0 \quad(n=6)$ ve eksitus oranı $\% 0.8(\mathrm{n}=1)$ saptanmıștır.

Daha önce intihar girişimi olanların \%23.1'i $(n=3)$ taburcu olurken, \% 46.2'si $(n=6)$ yatış ya da sevk oldu, daha önce intihar girişimi olmayanlarin ise \% 57'si ( $\mathrm{n}=61)$ taburcu olurken, $\% 20.6$ 's1 $(\mathrm{n}=22)$ yatış ya da sevk olmuştur.

İntihar şekline göre acile geliş süreleri arasında istatistiksel olarak anlamlı farklılık saptanmış olup; ilaç veya toksik madde ile intihar edenlerin acile geliş süreleri, diğer şekillerde intihar edenlerden anlamlı düzeyde yüksek bulunmuştur ( $\mathrm{p}=0.001$; Mann Whitney U Test).

İntihar şekline göre acilde kalış süreleri arasında istatistiksel olarak anlamlı farklılık saptanmış olup; ilaç veya toksik madde ile intihar edenlerin acilde kalış süreleri, diğer şekillerde intihar edenlerden anlamlı düzeyde yüksek bulunmuştur ( $\mathrm{p}=0.037$; Mann Whitney U Test).

Olguların \%82.5'ine $(\mathrm{n}=99)$ iki veya daha fazla, \%15.8'in $(n=19)$ bir ve \%1.7'sine $(n=2)$ hiç tedavi uygulanmadığını saptanmıștır. Hastaların $\% 80.8$ 'ine $(\mathrm{n}=97)$ nazogastrik tüp takılarak mide lavaj1 yapılmıș, \%85'ine $(n=102)$ aktif kömür verilmiş, \%80.8'ine $(\mathrm{n}=97)$ damar yolu açılarak serum fizyolojik verilmiş ve $\% 4.2$ 'sine $(n=5)$ sutür işlemi uygulanmıştı.

İstenen tetkikler incelendiğinde ise hastaların \%96.7'sinden $(\mathrm{n}=116)$ iki veya daha fazla, \%3.3'ünden $(n=4)$ bir tetkik istendiği bulunmuştur. Hastaların \%96.7'sinden $(n=116)$ hemogram ve biyokimya, \%81.7'sinden $(n=98)$ kan gaz1, \%84.2'sinden $(\mathrm{n}=101)$ kardiyak marker, $\% 26.7$ 'sinden $(n=32)$ etanol, \%2.5'inden $(n=3)$ röntgen \%4.2'sinden $(\mathrm{n}=5)$ Bilgisayarlı Beyin Tomografisi istenmişti.

Olguların acile geliş süreleri 10 ile 1430 dakika arasında değişmekte olup, ortalama $110.84 \pm 179.01$; acilde kalış süreleri 1 ile 24 saat arasında değişmekte olup, ortalama $10.36 \pm 6.59$ 'dur.

Acil hizmet bedelini acil muayene ve tetkik - tedavi maliyeti oluşturmakta olup, bu bedel 15.5- 


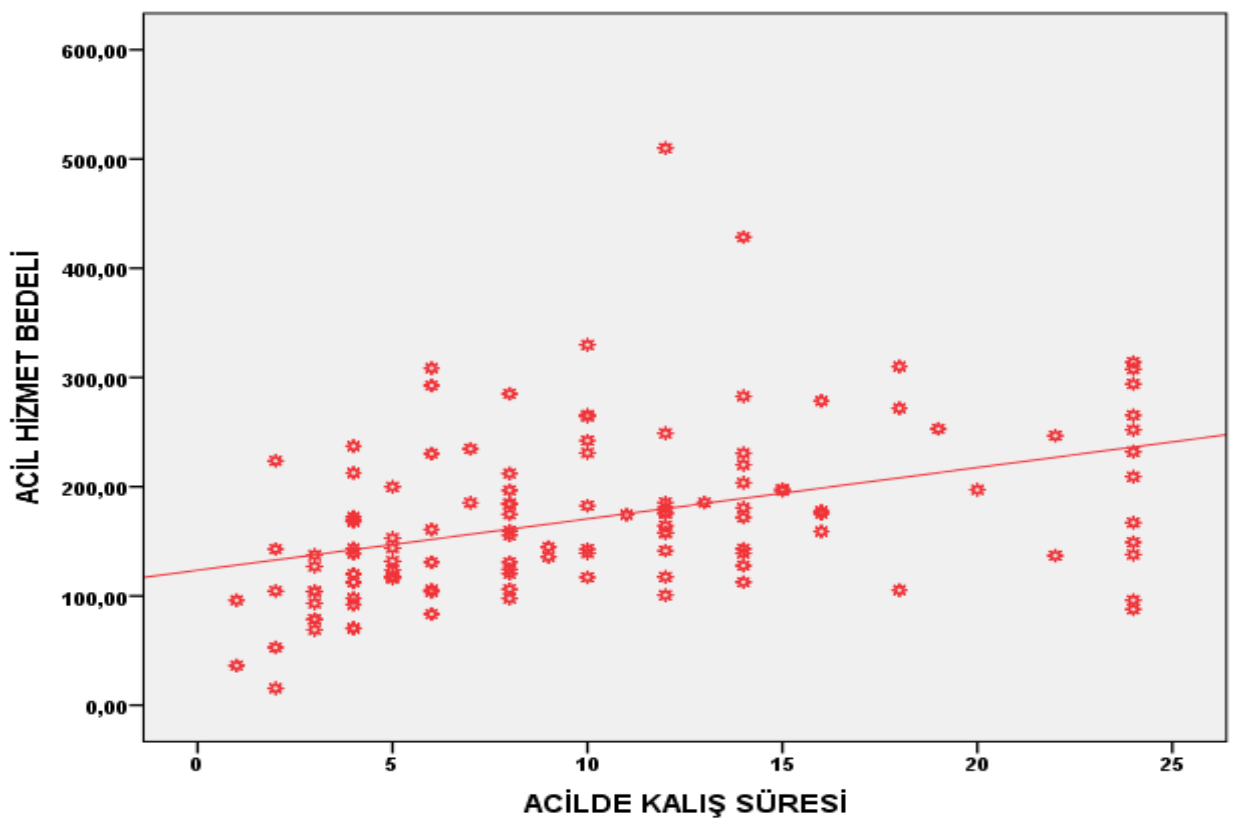

ile $510 \mathrm{TL}$ arasında değişmektedir ve ortalaması 172.25 \pm 76.65 TL'dir. Toplam maliyeti ise acil hizmet bedeline eklenen konsültasyon ücreti oluşturmakta olup ortalamas1 176.50土78.81 TL'dir.

Acil Serviste tedaviyi reddeden olguların hizmet bedeli, taburcu olanlardan $(\mathrm{p}=0.001)$, yatış yapilanlardan $(\mathrm{p}=0.028)$ ve sevk olanlardan $(\mathrm{p}=-$ 0.008) anlamlı düzeyde düşük bulunurken, diğer sonuçlar arasında istatistiksel olarak anlamlı farklılık saptanmamıştır $(\mathrm{p}>0,05)$.

İntihar şekline göre hizmet bedeli istatistiksel olarak anlamlı farklılık göstermemektedir ( $\mathrm{p}=0.379$, Mann Whitney U Test)

Acilde kalış süreleri ile hizmet bedeli arasında pozitif yönlü (kalış süresi arttıkça hizmet bedeli de artan) ve istatistiksel olarak da anlaml ilişki saptanmıştır ( $r=0.490 ; p=0.001$; Spearman's Korelasyon Katsayısı) (Şekil 3).

\section{Tartışma}

İntihar oldukça yaygın bir halk sağlığı problemi olup, DSÖ’nün verilerine göre gelişmiş ülkelerde en sik ölüm nedenleri arasında ilk on içerisinde yer almaktadır (10-11). İntihara bağlı ölümlerin son yıllarda genç erişkinlerde ve ergenlik döneminde sıklığının giderek artması dikkat çekicidir (12). Bu durum intihar girişimini gelişmiş ülkelerde önemli bir halk sağlığ 1 sorunu düzeyine getirmiştir (13). Biz bu çalışmada bir yıllık sürede acil servise başvuran intihar girişimlerinin demografik- sosyokültürel etkenlerini ve maliyet analizi sonuçlarını incelemeyi amaçladık.

Yapılan çalışmalarda intihar için genç yaş ve kadın olmanın risk faktörü olduğu belirtil-miştir (14). Dilbaz ve arkadaşları yaptıkları çalışmada intihar girişiminde bulunan 2775 kişide kadınların erkeklere oranını 2.17 olarak bulmuşlardır (15). Çok merkezli bir çalışmada Kerkhof ve Arensman birlikte intihar girişimininin kadınlarda 15-24 yaş grubunda, erkeklerde ise 25-34 yaş grubunda daha yüksek olduğunu tespit etmişlerdir (16). Bizim çalışmamızda acil servisimize başvuran hastaların \%73.3'ünü kadınlar (kadınların erkeklere oranı 2.75) oluşturmaktadır ve olguların yaş ortalaması 30.35 olarak saptanmıştır. Çalışmamızda intihar girişiminin en yüksek olduğu grup \%36.7 ile 18-24 yaş aralığı olarak saptandı. Kadınların erkeklere göre intihar girişimi riskinin yüksek olması kadının toplumdaki yeri ve konumu ile ilişkili olabilir. Kadınlar sıkıntılarını ve başkalarına tepkilerini ifade etmek için intihar girişimini bir yol olarak seçebilmektedir (17). Kekeç ve arkadaşları da yaptığı çalışmada kadınlarda intihar girişiminin yüksek olmasinın nedenleri arasında toplumlarda kadına yönelik baskıcı tutumun olduğu belirtilmiştir (18).

Çalışmamızda intihar eden kadınların \%96.6's1, erkeklerin \%84.4'ü lise ve altı düzeyinde eğitimi vardı. Üniversite mezunu olanlarda erkeklerin intihar oranı daha fazla olurken, lise ve 
altındaki öğrenimde kadınların oranı fazla bulundu. Bizim çalışmamızda olduğu gibi Sayıl ve arkadaşları da yaptığ çalışmada intihar girişiminde bulunanların \%93'ünün eğitim seviyelerinin lise ve altında olduğunu bulmuşlardır (19). Lonnqvist ve arkadaşlarının yaptığı bir çalışmada düşük eğitim seviyesinin intihar girişimi açısından risk oluşturduğu bulunmuştur (3). Sosyoekonomik düzeyin en önemli göstergelerinden biri eğitimdir. İntihar girişim oranının eğitim seviyesi düştükçe artmakta olduğu vurgulanmaktadır (20). Aynı zamanda eğitim seviyelerinin düşük olması kişinin sorun çözme becerilerinin yetersiz olmasına yol açarak bireylerin intihar eğilimlerinin artmasına neden olabilir.

Yalvaç ve arkadaşları yaptıkları çalışmada olguların \%52.0'ının evli olduğunu saptamış-lardır (21). Bu çalışmanın aksine Alptekin ve arkadaşları yaptıkları bir çalışmada intihar girişimiyle acil servise başvuran olguların \%63.8'inin bekar olduğunu belirlemişlerdir (22). Bizim çalışmamizda ise intihar eden hastaların medeni durumları göz önüne alındığında evli ve çalışan erkelerde kadınlara göre intihar girişimi fazla olurken (15'e 7) evli ve çalışmayan kadınlarda erkeklere göre intihar girişimi daha fazlaydı (11'e 5). Her iki cinsiyette bekarlar arasında çalışma durumunun intihar girişimi oranları benzerdi. Bekar kadınlarda iş durumundan bağımsız olarak daha fazla intihar girişimi olmuştu. Bizim bulgularımıza göre evli kadınlarda düzenli bir işte çalışıyor olmak (ev hanımlığına göre) intihar girişimini azaltmaktadır.

Avrupa'da yapılan çalışmalarda intihar girişiminde bulunan hastaların ekonomik düzeyi düşük kesimden ve sosyal yönden dengede olmamış bireyler olduğu görülmektedir (23). Sayıl ve arkadaşları genel olarak intihara karşı bir işte çalışıyor olmanın koruyucu bir etken olduğu ve işsizlerde intihar oranının daha yüksek olduğu bildirilmiştir (19). Güleç ve arkadaşları yaptığı çalışmada da intihar girişiminde bulunanların düzenli bir iş yaşamının ve güvencesinin olmadığ saptanmıştır (24). Çalışmamızda hastaların iş durumu incelendiğinde literatürle uyumlu olarak toplam 120 hastanın \%38.3'ünün belirli ve düzenli bir işi varken, $\% 28.3$ 'ünün herhangi bir işi bulunmamaktaydı. Hastaların \%33.4'ü ise ekonomik geliri olmayan ev hanımı ve öğrenciydi. Literatürde belirtildiği gibi işsizlik intihar eylemi ve intihar girişimlerinde önemli bir risk faktörüdür. İşsizlik kişinin ekonomik düzeyinin düşmesine buna bağlı olarak da yaşam kalitesinin düşmesine, temel ihtiyaçlarını karşılamada sorunlar yaşamasına neden olup bireyleri çaresiz bırakmaktadır.

Çalışmamızda en fazla intihar girişiminin 21.00-22.00 saat diliminde olduğu, intihar vakalarıyla acil servise başvuruların 18.00-23.00 saatleri arasında arttığ 1 ve en çok \%8.3 oranla 18.00 18.59 ve $22.00-22.59$ saat aralığında başvuru yapıldığı, acil servise intihar vakalarıyla başvuruların çoğunluğunun gece olduğu saptanmıştır. Ayrıca çalışmamızda ilaç veya toksik madde ile intihar edenlerin acile geliş süreleri ve acilde kalış süreleri, diğer şekillerde intihar edenlerden anlamlı düzeyde yüksek bulunmuştur ( $\mathrm{p}=0.001 ; \mathrm{p}=0.037$ ). Çalışma sonuçlarımıza yakın olarak Kekeç ve arkadaşları yaptıkları çalışmada intihar vakalarının en fazla 18.00-24.00 saatleri arasinda olduğunu saptamışlardır (24). Dilbaz ve arkadaşları da yaptığı çalışmada benzer sonuç olarak en çok intihar girişiminde bulunulan saati 23.00 olarak saptamışlardır (15). İntihar girişimlerinin, kişi gün içerisinde dikkatini iş, okul veya gün boyu devam eden diğer faaliyetlere yoğunlaştırdığından daha az gerçekleşmektedir. Ailenin tüm bireylerinin bir arada olduğu akşam saatlerinde, sorunlar sebebiyle kişiler arası çatışmalar daha yoğun yaşandığından intihar girişimlerinin akşam ve gece yoğunlaştığ 1 düşünülebilir.

Tüm intiharların \%19-24'ünde daha önce yapılmış intihar girişimleri bulunmakta ve bu intihar girişimlerinin de \%10'u 10 yll içinde intihar eylemi ile son bulmaktadır (26). Çalışmamızda intihar eden olguların \%1.7'sinin ailesinde ve $\% 10.8$ 'inde kendisinde daha önce intihar girişiminde bulunan bir birey olduğu, daha önce intihar girişimi olanların olmayanlara göre daha ciddi klinik sonuçlar doğurduğu ve yarıya yakınının gözlem için yatırıldığı bulundu.

Çalışmamızda ayrıca psikiyatrik tanı durumuna göre intihar şekli istatistiksel olarak anlamlı farklılık göstermezken ( $>0,05)$; ilaç veya toksik maddeyle intihar eden grupta psikiyatrik tan oranının yüksek olması dikkat çekicidir. Kubalı ve arkadaşları çalışmasında intihar girişiminde bulunanların daha önce intihar girişiminde bulunma oranını \%18.9 olarak saptamıştır (27). Deveci ve arkadaşlarının yaptığı çalışmada ise intihar girişiminde bulunanların \%8.8'inde ailede intihar girişimi bulunmuştur (28). Kubalı ise çalışmasında intihar girişiminde bulunanların \%8.4'ünün birinci derece akrabalarında intihar girişimi öyküsü, 
\%20'sinde psikiyatrik hastalık öyküsünün bulunduğunu göstermiştir (27). Psikiyatrik hastalıklar veya ailede psikiyatrik hastalığ olan birey varlığ kişinin ruhsal dengesini bozup sorunlar ile baş etmelerini etkileyebileceğini ve intihar girişimine neden olabileceğini düşünmekteyiz.

Çalışmamızda intihar girişiminde bulunun olguların \%80.0'inin intihar etme nedeninin aile içi sorunlar olduğu, bunu ise \%25.0 ile karşı cinsle sorunlar takip ettiği saptanmıştır. Yalvaç'ın çalışmasında intihar girişiminde en sik intihar nedeni olarak ailevi sorunların (\%50) neden olduğu tespit edilmiştir(21). Atlı çalışmasında da ilk sırada yer alan intihar girişim nedeni olarak aile içi geçimsizliği belirlemiştir (2). İntihar girişiminde bulunan bireyler genellikle ailelerini ilgisiz, kendisini reddeden ve destek olmayan bireyler olarak tanımlamaktadırlar. İntiharın etiyolojisinde aile yapısı, etkileșimi ve ilișkilerdeki sorunların önemli bir yere sahip olduğu düşünülmektedir (29).

Kişinin yaşadığı ortamın fiziki koşulları, sakin ya da şiddet unsurları içeren bir ölüm seçme eğilimi ve ölüm fikrinin ciddiyeti gibi faktörler intihar yöntemi seçiminde rol oynar (30). Alptekin ve arkadaşları yaptıkları çalışmalarda benzer şekilde intihar girişiminde bulunan vakaların kullandıkları yöntemlerde ilk sırada ilaç veya toksik madde alımı gelmekteydi (22). Tuan ve arkadaşları Vietnam'da yaptıkları çalışmada intihar vakalarının \%99'unda intihar şekli olarak ilaç veya toksik madde alımı, \%1'inde keskin cisimle temas ile girişimde bulundukları saptanmıştır (31). Şenol ve arkadaşları yaptıkları çalışmada başvuran hastalarda intihar yöntemlerinin başında ilaç alımının olduğunu ancak intihar eylemlerinde ilk sırada yüksekten atlama yönteminin olduğunu bildirmişlerdir (1). Bizim çalışmamızda ise ilaç veya toksik madde ile intihar etme oranı \%94.2, kesici alet ile intihar etme oranı \%2.5, kendini asarak intihar etme oranı \%1.7, ateşli silah ile intihar etme oran1 $\% 0.8$ ve yüksekten atlayarak intihar etme oranı $\% 0.8$ saptanmıştır. Çalışmamızın sonuçları literatürlerle genel olarak uyumlu bulunmuştur. İlaç veya toksik madde alımının daha fazla görülmesinin nedeni ilaçlara ulaşabilmenin kolay, yöntemin ağrısız ve ucuz olmasına bağlanmıştır. İntihar girişimlerinin çoğunda ilaç veya toksik madde alma yönteminin tercih edilme nedeni; kişi için ölümün temel gaye değil içinde bulunduğu duruma dikkat çekmek olduğu şeklinde açıklanabilir.
Hastaların son durumları incelendiğinde hastaların \%53.3'ünün acil servisten şifa ile taburcu olduğu, \%22.5'inin tetkik ve tedavisi bitmeden tedaviyi ret ettiği, \%18.4'ünün hastanemiz yoğun bakımında yer olmadığı ve psikiyatri servisinin bulunmadığından başka bir merkeze sevk edildiğini \%5.0'ının herhangi bir servise yatış verildiğini, \%0.8'inin ise acil servisimizde exitus olduğunu tespit ettik. Çalışma bulgumuza yakın olarak Şenol ve arkadaşları intihar girişimi nedeniyle acil servise başvuran 333 olgu ile yaptıkları çalışmada hastaların \%76'sının acil serviste takip edildiği, \%22.2'sinin de yoğun bakım ünitelerinde takip edildiğini saptamışlardır (1). Gökhan ve arkadaşlarının çalışmasında hasta-ların \%51.6'sinin acil serviste takip ve tedavisinin yapıldı̆̆ $1, \% 41$ 'inin ise dahiliye kliniğinde izlendiği bildirilmiştir (32). Kudo ve arkadaşlarının yaptığı çalışmada acil servise başvuran 1434 intihar vakasının \%5.9'u acil serviste eksitus olmuş, geri kalan 1348 hastanın \%33.1'i yoğun bakım ünitesine, $\% 33.8$ 'i ise hastanede ilgili bölüme yatırılarak takip edilmiş \%27.2'si de acil serviste tetkik ve tedavi sonrası taburcu edilmiştir. Sonuç olarak mortalite oranı $\% 5.9$ olarak tespit edilmiştir (33). Başvuruların acil klinik durum sebebiyle ve mesai saati dışında 24 saat hizmet veren acil servislere yapilması ve temel tedavilerin burada uygulanması beklenen bir bulgu olarak değerlendirilebilir. Yapılan çalışmalar değerlendirildiğinde intihar girişimi nedeni ile hastaneye başvuran vakaların büyük çoğunluğunun tedavi ve takiplerinin acil servislerde yapıldığını ve şifa ile taburcu olduklarını görmekteyiz. Bu nedenle acil serviste çalışan hekimlerin hastaları değerlendirirken; intihar girişiminin ortaya çıkarılmasına yönelik iyi bir anamnez alması, intihara sürüklenme nedeninin tespiti ve çözüme kavuşabilirliğini sağlamak ve tekrarını önlemek amacıyla hastalara ve yakınlarına durumu anlatarak psikiyatri polikliniğine yönlendirilmeleri gerekmektedir (34).

Literatür de intihar girişimi sebebiyle acil servise getirilen hastalardaki maliyet analizi ile ilgili veriler sınırlıdır ve acil servislerde maliyeti değiştiren verilerin değerlendirdiği çalışmalarda birçok parametreye bakılmadığı saptanmıştır. Bununla birlikte Nalliah ve arkadaşlarının 200 bin civarı çocuk intoksikasyonu değerlendirdiği çalışmada vaka başı acil servis maliyeti her başvuru için 1077\$ (dolar) olarak belirlenmiştir (35). 
Amerika Birleşik Devletleri'nde 2013 y1lı verilerine göre intihar girişimlerinin maliyeti 58.4 milyon dolar olarak tespit edilmiştir (36). Ülkemizde Serinken ve ark. yaptığı çalışmada ise hastaların ortalama maliyetin 144,06\$ olduğu rapor edilmiştir (37). Akar ve arkadaşları yaptığ 1 çalışmada ise intihar girişimlerinin hastane maliyetlerini 405,1 TL olarak bildirilmiştir (9). Bizim çalışmamızda intihar girişimi sebebiyle acil servis'e başvuran hastaların en düşük maliyeti hiçbir şey yapılmadan sadece yeşil alan muayene ücreti olan $15.5 \mathrm{TL}$, en yüksek maliyeti ise $510 \mathrm{TL}$ olup maliyet ortalamas1 172,25 TL, toplam maliyeti ise acil hizmet bedeline eklenen konsültasyon ücreti oluşturmakta olup ortalaması 176.50 TL bulunmuştur. Diğer çalışmaların sonuçlarına göre düşük saptanmasının sebebini çalışmamızda sadece hasta için harcanan hizmet bedeli dahil edilmiş olup, insan faktörü maliyetini dahil etmememize bağladık. Çalıșmamızın sonuçlarına göre intihar şekline göre hizmet bedeli arasında istatistiksel olarak anlamlı farklılık bulunmamıștır. Acilde kalış süreleri ile hizmet bedeli arasında pozitif yönlü (kalış süresi arttıkça hizmet bedeli de artan) istatistiksel olarak anlamlı ilişki saptanmıştır. Anestezi konsültasyonu istenen hastaların toplam maliyeti diğer konsültasyon istenen bölümlerden anlamlı düzeyde yüksek bulunmuştur.

\section{Sonuç}

İntihar eylemi ile başvuran hastaların yaklaşı yarısının tanı ve tedavi süreci Acil Serviste tamamlanmaktadır. Acilde kalış süresinin uzaması toplam maliyeti istatistiksel olarak arttırmaktadır. $\mathrm{Bu}$ hesaba doktor ve diğer sağlı personelinin hizmet maliyeti eklendiğinde bu maliyetin daha da yüksek olacağı aşikardır. Bu nedenle hastaların tanı ve takip sürecinde yeni protokoller geliştirilmelidir.

\section{Çalışmanın Sınırlılığı}

Maliyet analizi hesaplanması hastalık maliyetleri, hastalığın tanı ve tedavi sürecinde yapılan doğrudan sağlık harcamaları ve hastalığa bağlı işgücü kaybının neden olduğu dolaylı sağlık harcamalarını kapsar. Bu çalışmada maliyet bedel olarak bir hastanın hastane otomasyon sistemine kaydedilen muayene, tetkik, tedavi ve konsültasyon ücretleri değerlendirildi. Çalışan personel, doktor gibi ücretlerin hesaba katılmamas1 çalışmanın kısıtlılığı olarak kabul edilebilir.

\section{Kaynaklar}

1. Şenol V, Ünalan D, Avşaroğulları L, İkizceli İ. İntihar girişimi nedeniyle Erciyes Üniversitesi Tıp Fakültesi Acil Anabilim Dalı'na başvuran olguların incelenmesi. Anadolu Psikiyatri Dergisi. 2005; 6: 19-29.

2. Atlı Z. İntihar Olasılığı Ölçeği (İÖ)'nin Klinik Örneklemdeki Geçerlik ve Güvenirlik Çalışması. A.M.Ü. Sağllk Bilimleri Enstitüsü, Yüksek Lisans Tezi, Aydın, 2007.

3. Lonnqvist JK. Suicide: epidemiology and causes of suicide. New Oxford Textbook of Psychiatry. Gelder MG, López-Ibor pez-Ibor JJ, Andreasen N (eds). Oxford: Oxford University Press, 2000: 1033-1039.

4. Kposowa AJ: Unemployment and suicide: a cohort analysis of social factors predicting suicide in the US National Longitudinal Mortality Study. Psychol Med 2001; 31: 127-138.

5. Heikkinen A, Aro H, Lonnqvist J: Recent life events, social support and suicide. Acta Psychiatrica Scandinavica 1994; 377: 7-65.

6. Bekaroğlu M. Birinci Basamak İçin Acil Psikiyatri. İstanbul, Uniform Matbaası, 1998.

7. Yiğit Ç, Peker S, Cankul İ, Kostik Z, Alkan M, Özer $M$ ve ark. GATA Eğitim Hastanesinde Yatan Hasta Maliyetinin Belirlenmesi. Gülhane Tip Dergisi. 2003; 45: 233-243.

8. Talakacı S: Sağlık İşletmelerinde Maliyetlerin Belirlenmesi, Özel Sektör il Kamu Hastane İşletmelerinde Maliyet Analizi ve Bir Uygulama. Te Çalışması, Selçuk Üniversitesi Sosyal Bilimler Enstitüsü İşletme Anabili Dalı Muhasebe Finansman Bilim Dalı. Konya 2009: 8-95.

9. Akar T, Derinöz O, Demirel B. Drug intoxications and hospital costs. Turk Arch Ped 2007; 42: 103-106.

10. Mgaya E, Kazaura RM, Outwater A, Kinabo L. Suicide in the dar es salaam region, Tanzania, 2005. J Forensic Leg Med 2007; 30: 2-5.

11. Yüksel N. İntiharın Nörobiyolojisi. Klinik Psikiyatri Dergisi. 2001; 4: 5-15.

12. Dilsiz A, Dilsiz F. İntihar girişimlerinde belirtilen nedenler. Kriz Dergisi 1993; 1: 124- 129.

13. Tuzer $T$, Bayam $G$, Bitlis $V$. İntihar girişiminde yöntem seçimini etkileyen faktörler. Kriz Dergisi 1995; 3: 257-59.

14. Özgüven HD. İntiharlar ve İntihar Girişimlerinin Hızı ve Temel Sosyodemografik Özellikleri. Ankara Üniversitesi Tıp Fakültesi Psikiyatri Anabilim Dalı, 2004: 1-6.

15. Dilbaz N, Şengül CB, Çetin MK, Şengül C, Okay T, Yurtkulu F, Duman T. Genel bir hastanede intihar girişimlerinin değerlendirilmesi. Kriz Dergisi 2005; 13: 1-10.

16. Kerkhof AJFM, Arensman E. Attempted suicide and deliberate self harm epidemiology and risk factors. Gelder MG, Lopez JJ, Andreasen N (ed). Ne Oxford 
Text Book of Psychiatry First ed. Leiden University Press and World Healt Organization, 2000: 10391045.

17. Beautrais AL, Joyce PR ve Mulder RT. Personality traits and cognitive styles as risk factors for serious suicide attempts among young people. Suicide and Life-Threatening Behaviour, 1999; 29: 37-47

18. Kekeç Z, Sözüer EM, Duymaz H, Ökkan S. Acil Servise Başvuran Çoklu İlaç Zehirlenmelerinin Yedi Yıllık Analizi. Türkiye Acil Tıp Dergisi 2005; 5(2): 69-72.

19. Sayıl I, Devrimci-Ozguven H. Suicide and suicide attempts in Ankara in 1998: results of the WHO/EURO multicentre study on suicidal behaviour. Crisis 2002; 23: 11-16

20. Asoglu M. Sanlıurfa'da intihar Girisimlerinin iliskili Oldugu Risk Faktörleri. H.Ü. Tıp Fakültesi, Uzmanlık Tezi, Sanlıurfa, 2007

21. Yalvaç DH. İntihar Girişiminde Bulunan Bireylerde Psikiyatrik Morbidite, Kişilik Bozukluğu ve Bazı Sosyodemografik ve Klinik Etkenlerle İlişkisi (Uzmanlık Tezi). İnönü üniversitesi Tıp Fakültesi Psikiyatri A.D. Malatya, 2006.

22. Alptekin K, Duyan V, Demirel S. Adiyaman'da intihar girisimleri. Anadolu Psikiyatri Dergisi, 2006; 7: $150-56$

23. Schmidtke A. Attempted suicide in Europa: rates, trends and sociodemographic characteristics of suicide attempters during the period 1989- 1992. Results of the WHO/EURO Multicentre Study on Parasuicide. Acta Psychiatrica Scandinavica, 1996; 93: 327-338.

24. Güleç G, Aksaray G. İntihar Girișiminde Bulunan Gençlerin Sosyodemografik-Sosyokültürel ve Aile Özelliklerinin Değerlendirilmesi. Yeni Symposium 2006; 44: 141-150.

25. Kekeç Z, Yıldırım C, İkizceli İ, Gönül A, Sözüer E. Özkıyım girişimi nedeni ile acil servise başvuran hastalarda hazırlayıcı etkenler. Anadolu Psikiyatri Dergisi, 2000; 1: 157- 161

26. Sayar K, Acar B. Psikofarmakolojik ajanlarla yapılan intihar girişimlerinde risk etkenleri. Klinik Psikofarmakoloji Bülteni 199; 9: 208-212.

27. Kubalı Z. Ankara İlinde Bir Kamu Hastanesi Acil Bölümünde İntihar Girișim Vakalarının İncelenmesi. G.Ü. Sağlık Bilimleri Enstitüsü, Yüksek Lisans Tezi, Ankara, 2007.

28. Deveci A, Aydemir O, Mızrak S. İntihar girişiminde bulunanlarda sosyodemografik özellikler, stres etmenleri ve ruhsal bozukluklar. Kriz Dergisi. 2005; 13: 1-9.

29. Aktepe E, Kandil S, Göker Z, Topbaş KSM, Özkorumak E. İntihar girişiminde bulunan çocuk ve ergenlerde sosyodemografik ve psikiyatrik özelliklerin değerlendirilmesi. TAF Preventive Medicine Bulletin, 2006; 5: 444-454.
30. Palabıyıkoğlu R. İntihar Davranıșında Ailenin Rolü ve Önemi. A.Ü. T.F. Psikiyatrik Kriz Uygulama ve Araştırma Merkezi, Ankara, 1992.

31. Tuan VN, Dalman C, Le TC, Thiem V, Nguyen NV, Tran, Allebeck P. Suicide attempt in a rural area of Vietnam: incidence, methods used and access to mental health care. Int J Ment Health Syst 2010; 4: 3.

32. Gökhan S. Özkıyım nedeni ile acil servise basvuran Olguların demografik verilerinin özkıyım yöntemlerine göre degerlendirilmesi. T.C. Dicle Üniversitesi Tip Fakültesi Acil Tip AD, Tıpta uzmanlık tezi, Diyarbakır, 2008.

33. Kudo K, Otsuka K, Endo J, Yoshida T, Isono H, Yambe T, et al. Study of the outcome of suicide attempts: characteristics of hospitalization in a psychiatric ward group, critical care center group, and nonhospitalized group; BMC Psychiatry 2010; 10: 4-5.

34. Yanturalı S. Acil serviste intihar düš̈ncesi olan hastaya yaklaşım. Acil Tıp Dergisi 2000; 3: 246-253.

35. Nalliah RP, Anderson IM, Lee MK, Rampa S, Allareddy V, Allareddy V. Children in the United States make close to 200, 000 emergency department visits due to poisoning each year. Pediatr Emerg Care. 2014; 30(7): 7-453.

36. Shepard DS, Gurewich D, Lwin AK, Reed GA Jr, Silverman MM. Suicide and Suicidal Attempts in the United States: Costs and Policy Implications. Suicide Life Threat Behav. 2016 Jun;46(3):352-62.

37. Serinken M, Karcioglu O, Sengul C, Turkcuer I, Keysan MK. Hospital costs of managing deliberate self-poisoning in Turkey. Med Sci Monit. 2008; 14(3): 152-158. 